\title{
SUBSTRATE TYPE AS A SELECTIVE TOOL AGAINST COLONIZATION BY NON-NATIVE SESSILE INVERTEBRATES
}

\author{
Leonardo C. Cangussu, Luciana Altvater, Maria Angélica Haddad, Ana Caroline Cabral, Halina Linzmeier \\ Heyse and Rosana M. Rocha*
}

Universidade Federal do Paraná - Departamento de Zoologia (Caixa Postal 19020, 82531-980 Curitiba, PR, Brasil)

*Corresponding author: rmrocha@ufpr.br

\begin{abstract}
A B S T R A C T
Different substrates of varying composition, color, texture and orientation may selectively influence recruitment of sessile invertebrates and thereby influence the resultant community. Thus substrates may act as a barrier to the establishment of non-indigenous species (NIS). In southern Brazil, granite is the main rock forming natural rocky walls that are available for encrusting organisms. In this study we tested whether granite selectively influences recruitment and impedes colonization by introduced and cryptogenic species that are already established on artificial substrates within the region. Plates of rough cut granite and of polyethylene were made available each month under a pier at a yacht club in Paranaguá Bay. A community is already established on concrete columns and fiber glass floats on the piers. After one, two and twelve months, the faunal composition of the plates was compared between the two treatments and other artificial substrates. Granite was recruited by all the seven introduced species found in the Bay and by 18 of 26 cryptogenic species and therefore is ineffective as a barrier to NIS colonization.
\end{abstract}

\section{RESUMO}

Substratos de diferentes materiais, cores, texturas e orientação podem influenciar seletivamente no recrutamento de invertebrados sésseis e, assim, influenciar a comunidade resultante. Deste modo, o substrato pode funcionar como barreira contra o estabelecimento de espécies não nativas (NIS, na sigla em inglês). No sul do Brasil, o granito é a principal rocha formadora de costões rochosos naturais disponíveis para organismos incrustantes. Nesta investigação, nós testamos se o granito seleciona o recrutamento de espécies e se poderia, assim, impedir a colonização de espécies introduzidas ou criptogênicas já estabelecidas em substratos artificiais na região. Placas não polidas de granito e de polietileno foram submersas a cada mês em um píer de um iate clube na Baía de Paranaguá. Há uma comunidade já estabelecida sobre colunas de concreto e sobre flutuadores de fibra de vidro presentes no iate clube. Depois de um, dois e doze meses, as espécies presentes nas placas de diferentes materiais foram comparadas entre si e também com outros substratos. $\mathrm{O}$ granito foi colonizado por todas as sete espécies introduzidas encontradas na região, e por 18 das 26 espécies criptogênicas, sendo então ineficaz como barreira contra a colonização de NIS.

Descriptors: Introduced species, Recruitment, Bioinvasion, Artificial substrata, Granite, Estuaries, Conservation, Paranaguá Bay.

Decritores: Espécies introduzidas, Recrutamento, Bioinvasão, Substrato artificial, Granito, Estuário, Conservação, Baía de Paranaguá.

\section{INTRODUCTION}

Non-indigenous marine species (NIS) are continuously spread throughout the world by human maritime activities and constitute one of the major global changes associated with the oceans (RUIZ et al., 1997). Ship transport is a known vector with a long history of dispersal of species throughout the oceans in a variety of ways: in ballast water, encrusted on hulls and in sea chests (COUTTS et al., 2003).
NIS, when arriving in a new environment, are subject to the availability of local resources for their survival and subsequent establishment of populations. Adverse conditions or resource limitation may be barriers that impede the establishment of NIS. For benthic sessile organisms, space for attachment and growth is one of the main limiting resources that may prevent a species from becoming established.

In coastal environments, humans continuously build new structures and add artificial hard substrates that remain immersed and, therefore, 
available for attachment by encrusting organisms. Such structures are usually made of concrete, wood, PVC, other plastic materials, fiberglass and so on. Recent studies find that these structures are colonized first by NIS and act as stepping stones for the colonization of natural habitats (CONNEL and GLASBY, 1999). On the other hand, even if established on artificial substrates, NIS may only become a threat to natural communities once they colonize natural substrates.

Substrates themselves can favor establishment of certain species because of their chemical composition (BAVESTRELLO et al., 2000; GLASBY and CONNEL, 2001; KNOTT et al., 2004; ANDERSSON et al., 2009), color, texture (SKINNER and COUTINHO, 2005; FLORES and FAULKNES, 2008), depth and orientation. Thus, substrate characteristics may be barriers to colonization by NIS, thereby preventing their invasion. Different substrate characteristics may be associated with different species compositions or abundances (GLASBY, 2000; CONNELL, 2001; BULLERI and CHAPMAN, 2004; BULLERI, 2005; STACHOWICZ et al., 2007). On the other hand, recruitment by some NIS is possible on a large variety of substrates and this opportunism permits their successful invasion (CREED and PAULA, 2007).

Concrete columns, floating fiberglass and floating hulls comprise distinct habitats each with their own communities of different species (NEVES et al., 2007). However, temporal variation as part of the wider picture is unknown here, but it has been shown to exert an important influence on communities and should be considered when comparing natural and artificial substrates (GLASBY, 2000). In this study, we test whether granite, the natural substrate of rocky marine habitats in southern Brazil, acts as a selective barrier to recruitment, thereby reducing colonization by introduced or cryptogenic species. The experiment was carried out over one year to include temporal variation in the recruitment process.

\section{Material And Methods \\ Study Area}

Substrate plates in two different treatments were placed at the Paranaguá Yacht Club, in the Itiberê river near its mouth in Paranaguá Bay (2531'S, 48³0'W, Fig. 1). Paranaguá Bay is part of a large estuarine complex in the southern Brazilian coastal states of Paraná and São Paulo. This estuarine system is connected to the sea by three channels, the main one located close to Mel Island (LANA et al., 2001). Water circulation and stratification patterns inside Paranaguá Bay change during the year, with variation in salinity (12 - 29 in summer, $20-34$ in winter), and temperature $\left(23-30^{\circ} \mathrm{C}\right.$ in summer, 18 $25^{\circ} \mathrm{C}$ in winter) (LANA et al., 2001).

The Itiberê River skirts the city of Paranaguá, separating Valadares Island from the continent. Its margins were originally mangrove swamps that were destroyed as a result of the expansion of the city (CANEPARO, 2000). Now only small mangrove forest fragments remain, the roots of which, along with the columns of many piers, are covered by encrusting communities.

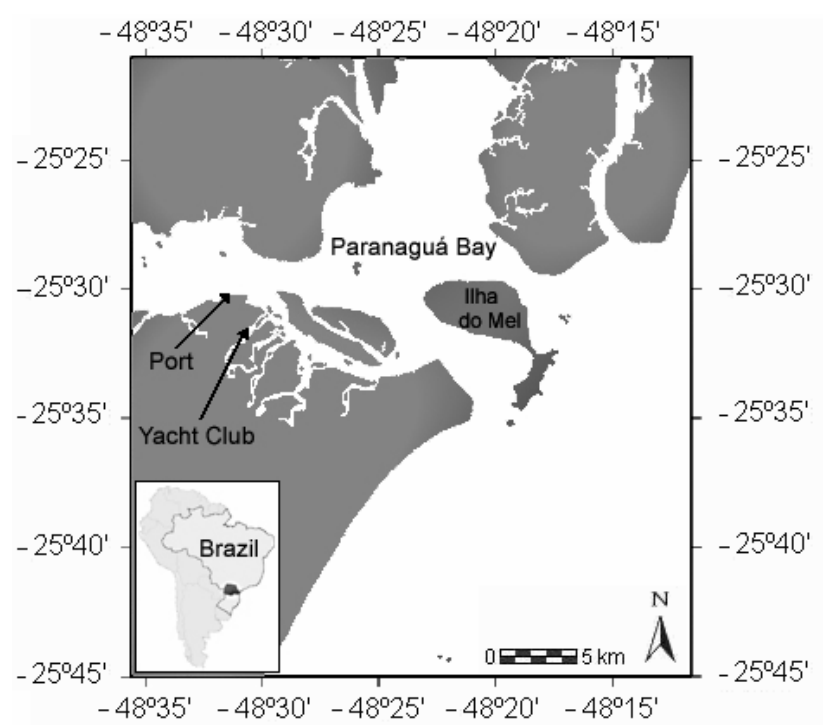

Fig.1. Map of Paranaguá Bay showing location of study area and of the port of Paranaguá. In the detail the map of Brazil showing the state of Paraná. 
The Yacht Club has two main piers with a central walkway supported by concrete columns and lateral floating fiberglass docks, covered with wood. The international port of Paranaguá, the most important port in southern Brazil, is less than $1 \mathrm{~km}$ from the Yacht Club. As larger ships became more frequent, the port was forced to move from the city to its current location in 1935 (GODOY, 2000).

\section{Field Experiment}

Each month, 10 plates $(23.0 \times 11.5 \mathrm{~cm})$ of rough-cut granite and six plates $(14 \times 14 \mathrm{~cm})$ of black polyethylene plastic were hung from the floating docks at the Yacht Club from March/2007 to February/2008. Bricks were attached to each rope at $1.5 \mathrm{~m}$ depth to maintain the plates in a vertical position and reduce the influence of tidal drag. One month after plates had been submerged they were removed from the water, photographed (granite) or examined under a stereomicroscope (plastic), and then replaced in their previous positions, where they remained for another month (i.e., for a total of 2 months). Also, at the beginning of the experiment, another 10 granite and six plastic plates were put in place where they remained for an entire year. Upon collection, plates were fixed in formalin $4 \%$ after treatment in sea water with menthol crystals for $2 \mathrm{~h}$. Plastic and granite plates were on the same ropes, and so had a slight difference in depth, but both were always submerged.

\section{Plate Analysis}

Species were counted on the exposed surfaces of the granite plates in 15 squares of a $3.6 \mathrm{~cm}^{2}$ grid, equivalent to $30 \%$ of the total plate area. Species were counted on plastic plates in 21 squares of a 1.4 $\mathrm{cm}^{2}$ grid $(21 \%$ of the total plate area). Specialists for each taxon were provided with voucher samples for their identification. Species were classified as native, introduced or cryptogenic, following the literature, based on their origin and current geographical distribution (CARLTON, 1996) and on other criteria, such as presence on artificial substrates, ports and marinas, disjointed distribution and rapid dispersion in a region (CHAPMAN and CARLTON 1991, 1994). Historical data regarding encrusting species in the region are relatively recent, with the oldest study of fouling communities dating from 1987-88 (CORREIA and SILVA, 1990). We compared our list of species with those of the latter study and with those of NEVES et al. (2007) and NEVES and ROCHA (2008) to better understand the recent invasion history of the Bay and evaluate the ability of each species to colonize different types of substrates.

\section{RESULTS}

A total of sixty-two taxa were found. Of these, 44 species were identified, eight of which were native, seven were introduced, three historically introduced and 26 were cryptogenic (Table 1). The native species to Paranaguá Bay were: Fistulobalanus citerosum (Cirripedia), Nicolea uspiana, Pseudobranchiomma paulista and Branchiomma patriota (Polychaeta), Mytella charruana, Crassostrea rhizophorae and Ostrea puelchana (Bivalvia), and Molgula phytophila (Ascidiacea). The Brazilian endemics include Nicolea uspiana, $P$. paulista, $B$. patriota and $M$. phytophila, the first three of which are here reported for the first time in Paraná. Fistulobalanus citerosum occurs, in Brazil, from Pernambuco to Rio Grande do Sul. The bivalve $O$. puelchana occurs along the southeastern and southern coasts, while M. charruana and C. rhizophorae are more widespread (Table 1).

Of the introduced species, the octocoral Carijoa riisei, the bivalve $P$. perna and the barnacle $M$. tintinnabulum were probably introduced into Brazil long ago and are now considered naturalized. The polyp of the hydroid $H$. carnea and the serpulid $H$. sanctaecrucis are here reported for the first time in southern Brazil. The other introduced species included the hydrozoan Garveia franciscana, the barnacles Amphibalanus reticulatus, Megabalanus coccopoma and Striatobalanus amaryllis, and the ascidian Styela plicata, of which only M. coccopoma was previously unknown in Paranaguá Bay (Table 1).

Most of the species were classified as cryptogenic due to the lack of historical distributional information. Many have wide geographical distribution with unknown native ranges or disjunct populations. This category comprises nine hydrozoans, one anthozoan, seven bryozoans, one bivalve, one polychaete, four barnacles and three ascidians (Table 1).

Species did not occur synchronously on the granite plates, but rather some were restricted to a single month while others appeared throughout the year (Table 2). At least one introduced species appeared on granite plates each month: in summer Garveia franciscana, Amphibalanus reticulatus and Striatobalanus amaryllis; in the fall A. reticulatus and Megabalanus coccopoma; in winter A. reticulatus, $M$. coccopoma and Styela plicata; in the spring $H$. sanctaecrucis, A. reticulatus and $S$. plicata. Rare species were found on $\leq 10 \%$ of the plates, while common species were found on all plates. 
Table 1. Taxa found at Paranaguá Yacht Club on granite and polyethylene plates in the years 2007-2008, with introduction status and geographical distribution.

\begin{tabular}{|c|c|c|c|}
\hline Taxa & Status $^{1}$ & Geographical distribution & References \\
\hline \multicolumn{4}{|l|}{ Porifera } \\
\hline Porifera sp. 1 & - & - & \\
\hline Porifera sp. 2 & - & - & \\
\hline \multicolumn{4}{|l|}{ Hydrozoa } \\
\hline Bouganvillia muscus (Allman, 1863) & $\mathrm{C}$ & $\begin{array}{l}\text { Atlantic, Pacific, Indian Ocean, Mediterranean, } \\
\text { Brazil (RJ- PR) }\end{array}$ & $\begin{array}{l}\text { Calder, 1988; Migotto et al., } \\
2002\end{array}$ \\
\hline Clytia gracilis (M. Sars, 1850) & $\mathrm{C}$ & $\begin{array}{l}\text { Circumglobal, Atlantic, Indian and Pacific } \\
\text { oceans, Brazil (PE, ES-PR, RS) }\end{array}$ & $\begin{array}{l}\text { Millard, 1975; Migotto et al., } \\
2002\end{array}$ \\
\hline Clytia linearis (Thornely, 1899) & $\mathrm{C}$ & $\begin{array}{l}\text { Western and Eastern Atlantic, Indian Ocean, } \\
\text { West and East Pacific, Brazil (ES, SP, PR) }\end{array}$ & $\begin{array}{l}\text { Calder, 1988; Migotto et al., } \\
2002\end{array}$ \\
\hline $\begin{array}{l}\text { Ectopleura dumortieri (Van } \\
\text { Beneden, 1844) }\end{array}$ & $\mathrm{C}$ & $\begin{array}{l}\text { Cosmopolitan, Atlantic Ocean, Mediterranean } \\
\text { Sea, North Sea, Brazil (RJ-RS) }\end{array}$ & $\begin{array}{l}\text { Migotto, 1996; Migotto et al., } \\
\text { 2002; Galea et al. } 2007\end{array}$ \\
\hline Eudendrium carneum Clarke, 1882 & $\mathrm{C}$ & $\begin{array}{l}\text { Atlantic, Indian Ocean, East Pacific, Clarion } \\
\text { Island, Brazil (FN, PE, BA-SC) }\end{array}$ & $\begin{array}{l}\text { Calder, 1988; Migotto et al., } \\
2002\end{array}$ \\
\hline Garveia franciscana Torrey, 1902 & I & $\begin{array}{l}\text { North Atlantic, Gulf of Mexico, West Africa, } \\
\text { India, North Pacific, Mediterranean Sea, } \\
\text { Australia, Brazil (PE, PR) }\end{array}$ & $\begin{array}{l}\text { Medel and López-Gonzales, } \\
\text { 1996; Migotto et al., 2002; } \\
\text { Cairns et al., 2003; Neves and } \\
\text { Rocha, } 2008\end{array}$ \\
\hline Hydractinia carnea (M. Sars, 1846) & I & $\begin{array}{l}\text { Cosmopolitan, Brazil - only medusa stage (SP, } \\
\text { PR), }\end{array}$ & $\begin{array}{l}\text { Migotto et al., 2002; Cairns et } \\
\text { al., 2003; Bisby et al., } 2005\end{array}$ \\
\hline Obelia bidentata Clarke, 1875 & $\mathrm{C}$ & $\begin{array}{l}\text { Circumtropical, West and East Atlantic, Indian } \\
\text { Ocean, West and East Pacific, Brazil (PE, RJ- } \\
\text { SP, PR) }\end{array}$ & $\begin{array}{l}\text { Calder, 1988; Correia and } \\
\text { Silva, 1990; Migotto et al., } \\
2002\end{array}$ \\
\hline Obelia dichotoma (Linnaeus, 1758) & $\mathrm{C}$ & Cosmopolitan, Brazil (ES-PR, RS) & $\begin{array}{l}\text { Calder, 1988; Migotto et al., } \\
\text { 2002, Galea et al., } 2007\end{array}$ \\
\hline $\begin{array}{l}\text { Pinauay crocea }(\text { Agassiz, 1862) }(=P \text {. } \\
\quad \text { ralphi } \text { Bale, } 1884)\end{array}$ & $\mathrm{C}$ & $\begin{array}{l}\text { Atlantic, Indian Ocean, South Africa, Brazil } \\
\text { (ES-RS) }\end{array}$ & $\begin{array}{l}\text { Millard, 1975; Migotto et al., } \\
2002\end{array}$ \\
\hline Plumularia floridana Nutting, 1900 & $\mathrm{C}$ & Cosmopolitan, Brazil (PE, ES-SP) & $\begin{array}{l}\text { Calder, 1997; Migotto et al., } \\
2002\end{array}$ \\
\hline Tubulariidae (1 species) & - & - & \\
\hline \multicolumn{4}{|l|}{ Anthozoa } \\
\hline Actiniaria & - & - & \\
\hline Aiptasia pallida (Verrill, 1864) & $\mathrm{C}$ & $\begin{array}{l}\text { United States, Gulf of Mexico, Brazil (RN, PE, } \\
\text { BA-SC) }\end{array}$ & $\begin{array}{l}\text { Gomes and Mayal, 1997; } \\
\text { Schlenz et al., 1998; }\end{array}$ \\
\hline Diadumene sp. & - & - & \\
\hline Clavulariidae (1 species) & - & - & \\
\hline $\begin{array}{l}\text { Carijoa riisei (Duchassaing and } \\
\text { Michelotti, 1860) }\end{array}$ & HI & Circumtropical, Brazil (AP-SC) & Concepcion et al 2010 \\
\hline \multicolumn{4}{|l|}{ Bryozoa } \\
\hline Alcyonidium sp. & - & - & \\
\hline Biflustra denticulata (Busk, 1856) & $\mathrm{C}$ & $\begin{array}{l}\text { East Pacific, United States (Gulf of California } \\
\text { and Cape Hatteras), Colombia, Brazil (ES, SP, } \\
\text { PR, SC) }\end{array}$ & $\begin{array}{l}\text { Winston, 2005; Montoya- } \\
\text { Cadavid et al., 2007; Vieira et } \\
\text { al., } 2008\end{array}$ \\
\hline Bugula neritina (Linnaeus, 1758) & $\mathrm{C}$ & Cosmopolitan, Brazil (RJ, SP, PR, SC) & $\begin{array}{l}\text { Orensanz et al., 2002; } \\
\text { Ramalho et al., 2005; Wyatt et } \\
\text { al., 2005; Vieira et al., } 2008\end{array}$ \\
\hline Bugula stolonifera Ryland, 1960 & $\mathrm{C}$ & Cosmopolitan, Brazil (RJ, SP) & $\begin{array}{l}\text { Orensanz et al., 2002; } \\
\text { Ramalho et al., 2005; Wyatt et } \\
\text { al., 2005; Vieira et al., } 2008\end{array}$ \\
\hline $\begin{array}{l}\text { Conopeum reticulum (Linnaeus, } \\
1767 \text { ) }\end{array}$ & $\mathrm{C}$ & $\begin{array}{l}\text { Cosmopolitan except polar regions, Brazil } \\
\text { (ES-SC) }\end{array}$ & Vieira et al., 2008 \\
\hline Conopeum $s p$ & - & - & \\
\hline
\end{tabular}


Table 1. Continuation.

\begin{tabular}{|c|c|c|c|}
\hline Taxa & Status1 & Geographical distribution & References \\
\hline Electra tenella (Hincks, 1880) & $\mathrm{C}$ & $\begin{array}{l}\text { United States (Florida), Puerto Rico, } \\
\text { Colombia, Mediterranean, India, Japan, New } \\
\text { Zeland, Brazil (SP, PR) }\end{array}$ & $\begin{array}{l}\text { Winston, 1982; Badve and } \\
\text { Sonar, 1995; Streftaris et al., } \\
\text { 2005; Montoya-Cadavid et al., } \\
\text { 2007; Vieira et al., } 2008\end{array}$ \\
\hline $\begin{array}{l}\text { Hippoporina verrilli Maturo and } \\
\text { Schopf, } 1968\end{array}$ & $\mathrm{C}$ & $\begin{array}{l}\text { West Atlantic, East Pacific, Galapagos, Brazil } \\
\text { (SP, PR) }\end{array}$ & $\begin{array}{l}\text { Winston, 1982; Vieira et al., } \\
2008\end{array}$ \\
\hline Sinoflustra annae (Osburn, 1953) & $\mathrm{C}$ & $\begin{array}{l}\text { United States (Florida, Texas, California), } \\
\text { Canada (Vancouver, Queen Charlotte Islands), } \\
\text { Panama, West Africa, Japan, Brazil (SP, PR) }\end{array}$ & $\begin{array}{l}\text { Hastings, 1930; McCann et } \\
\text { al., 2007; Vieira et al., } 2008\end{array}$ \\
\hline Ctenostomata (1 species) & - & - & \\
\hline \multicolumn{4}{|l|}{ Bivalvia } \\
\hline Brachidontes sp. & - & - & \\
\hline $\begin{array}{l}\text { Crassostrea rhizophorae (Guilding, } \\
1828 \text { ) }\end{array}$ & $\mathrm{N}$ & $\begin{array}{l}\text { Venezuela, Suriname, Uruguay, Brazil (AP- } \\
\text { RS) }\end{array}$ & Rios, 1994 \\
\hline Hiatella sp. & - & - & \\
\hline Musculus lateralis (Say, 1822) & $\mathrm{C}$ & $\begin{array}{l}\text { United States (North Carolina-Texas), West } \\
\text { Indies, Brazil (PE-SC). }\end{array}$ & Rios, 1994 \\
\hline Mytella charruana (Orbigny, 1842) & $\mathrm{N}$ & $\begin{array}{l}\text { Mexico, Ecuador, Galapagos, Venezuela, } \\
\text { Suriname, Brazil (PB-PR), Uruguay, } \\
\text { Argentina, }\end{array}$ & $\begin{array}{l}\text { Rios, 1994; Junqueira et al., } \\
2004\end{array}$ \\
\hline $\begin{array}{l}\text { Ostrea puelchana } \\
\text { Orbigny, } 1841\end{array}$ & $\mathrm{~N}$ & Brazil (RJ-RS), Argentina & Rios, 1994 \\
\hline Perna perna (Linnaeus, 1758) & $\mathrm{HI}$ & $\begin{array}{l}\text { Mediterranean, Senegal, South Africa, Brazil } \\
\text { (ES-RS). }\end{array}$ & Rios, 1994 \\
\hline \multicolumn{4}{|l|}{ Polychaeta } \\
\hline $\begin{array}{l}\text { Branchiomma patriota Nogueira } \text { et } \\
\text { al., } 2006\end{array}$ & $\mathrm{~N}$ & Brazil (SP) & Nogueira et al., 2006 \\
\hline $\begin{array}{l}\text { Hydroides sanctaecrucis Krøyer in } \\
\quad \text { Mörch, } 1863\end{array}$ & I & $\begin{array}{l}\text { Dutch Antilles, French Guiana, Haiti, Gulf of } \\
\text { Mexico, Panama; Mexico (Pacific coast), } \\
\text { Hawaii, Australia, Brazil (PR) }\end{array}$ & $\begin{array}{l}\text { Hayes et al., 2005; Lewis et } \\
\text { al., } 2006\end{array}$ \\
\hline $\begin{array}{l}\text { Neanthes cf. succinea (Frey and } \\
\text { Leuckart, 1847) }\end{array}$ & $\mathrm{C}$ & Cosmopolitan, Brazil (RJ-PR, RS) & Fauchald, 1977 \\
\hline Nicolea uspiana Nogueira, 2003 & $\mathrm{~N}$ & Brazil (PE, SP) & $\begin{array}{l}\text { Nogueira, 2003; Nascimento } \\
\text { et al., } 2007\end{array}$ \\
\hline \multicolumn{4}{|l|}{ Nicolea $\mathrm{sp}$} \\
\hline $\begin{array}{l}\text { Pseudobranchiomma paulista } \\
\quad \text { Nogueira et al., } 2006\end{array}$ & $\mathrm{~N}$ & Brazil (SP) & Nogueira et al., 2006 \\
\hline Pseudobranchiomma sp. & - & - & \\
\hline Serpula sp. & - & - & \\
\hline \multicolumn{4}{|l|}{ Cirripedia } \\
\hline $\begin{array}{l}\text { Amphibalanus amphitrite (Darwin, } \\
\text { 1854) }\end{array}$ & $\mathrm{C}$ & Cosmopolitan, Brazil (AP-RS) & Rocha, 1999; Farrapeira, 2009 \\
\hline Amphibalanus eburneus (Gold, 1841) & $\mathrm{C}$ & Cosmopolitan, Brazil (PE, RJ, SP, PR) & Farrapeira, 2009 \\
\hline $\begin{array}{l}\text { Amphibalanus improvisus (Darwin, } \\
\text { 1854) }\end{array}$ & $\mathrm{C}$ & Cosmopolitan, Brazil (CE-RS) & Farrapeira, 2009 \\
\hline $\begin{array}{l}\text { Amphibalanus reticulatus (Utinoni, } \\
\text { 1967) }\end{array}$ & I & Circumtropical, Brazil (PE, BA, RJ -SC) & Farrapeira, 2009 \\
\hline Balanus trigonus (Darwin, 1854) & $\mathrm{C}$ & Cosmopolitan, Brazil (AP-RS) & $\begin{array}{l}\text { Apolinário, 2002; Orensanz et } \\
\text { al., 2002; Zullo, } 1992\end{array}$ \\
\hline $\begin{array}{l}\text { Fistulobalanus citerosum (Henry, } \\
\text { 1974) }\end{array}$ & $\mathrm{N}$ & Brazil (PB-RS) & Neves and Rocha, 2008 \\
\hline $\begin{array}{l}\text { Megabalanus coccopoma } \\
\text { (Darwin, 1854) }\end{array}$ & I & $\begin{array}{l}\text { United States (East coast), Gulf of Mexico, } \\
\text { Belgium, Northeast Pacific, Brazil (PE-RS) }\end{array}$ & $\begin{array}{l}\text { Apolinário, 2002; Farrapeira } \\
\text { et al., } 2007\end{array}$ \\
\hline $\begin{array}{l}\text { Megabalanus tintinnabulum } \\
\quad \text { (Linnaeus, 1758) }\end{array}$ & HI & Cosmopolitan, Brazil (PI-RS) & Farrapeira, 2009 \\
\hline
\end{tabular}


Table 1. Continuation.

\begin{tabular}{|c|c|c|c|}
\hline Taxa & Status1 & Geographical distribution & References \\
\hline $\begin{array}{l}\text { Striatobalanus amaryllis Darwin, } \\
1854\end{array}$ & I & Cosmopolitan, Brazil: PI, PE, BA, PR & Farrapeira, 2009 \\
\hline \multicolumn{4}{|l|}{ Amphipoda } \\
\hline Jassa sp. & - & - & \\
\hline Laticorophium sp. & - & - & \\
\hline Monocorophium sp. & - & - & \\
\hline \multicolumn{4}{|l|}{ Ascidiacea } \\
\hline $\begin{array}{l}\text { Diplosoma listerianum (Milne- } \\
\text { Edwards, 1841) }\end{array}$ & $\mathrm{C}$ & Cosmopolitan, Brazil (BA-SC) & Rocha and Kremer, 2005 \\
\hline $\begin{array}{l}\text { Microcosmus exasperatus Heller, } \\
1878\end{array}$ & $\mathrm{C}$ & Circumtropical, Brazil (PE, BA, RJ-SC) & Rocha and Kremer, 2005 \\
\hline Molgula phytophila Monniot 1970 & $\mathrm{~N}$ & Brazil (RJ-SC) & $\begin{array}{l}\text { Rocha and Kremer, 2005; } \\
\text { Rocha and Moreno, } 2000\end{array}$ \\
\hline Polycarpa sp. & - & - & \\
\hline Styela plicata (Lesueur, 1823) & I & Cosmopolitan, Brazil (PE, BA, RJ-SC) & $\begin{array}{l}\text { Rocha and Kremer, 2005; } \\
\text { Farrapeira et al., 2007; Barros } \\
\text { et al., } 2009\end{array}$ \\
\hline Symplegma rubra Monniot, 1972 & $\mathrm{C}$ & $\begin{array}{l}\text { United States, Caribbean, Indian ocean, } \\
\text { Pacific, Brazil (RJ-SC) }\end{array}$ & Rocha and Kremer, 2005 \\
\hline
\end{tabular}

${ }^{1}$ Status: $\mathrm{I}=$ introduced, $\mathrm{HI}=$ historic introduction, $\mathrm{N}=$ native, $\mathrm{C}=$ cryptogenic

Table 2. Taxa present on granite plates with frequency and period of occurrence. NIS species in bold type.

\begin{tabular}{|c|c|c|c|c|c|}
\hline Taxa & $\begin{array}{c}\text { Frequency } \\
(\%)\end{array}$ & Months of occurrence & Taxa & $\begin{array}{c}\text { Frequency } \\
(\%)\end{array}$ & $\begin{array}{l}\text { Months of } \\
\text { occurrence }\end{array}$ \\
\hline Clytia gracilis + Obelia $\mathrm{spp}$ & 89.7 & Apr - Jan & Branchiomma patriota & 10 & $\mathrm{Feb}$ \\
\hline Ectopleura dumortieri & 30 & Aug - Sep & Hydroides sanctaecrucis & 30 & Nov \\
\hline Garveia franciscana & 25 & Dec - Mar & Nicolea uspiana & 55.1 & Feb - Dec \\
\hline Hydractinia carnea & 62 & Feb -May, Sep & Pseudobranchioma sp. & 49.5 & Feb - Dec \\
\hline Pinauay crocea & 10 & Aug & $\begin{array}{l}\text { Pseudobranchiomma } \\
\text { paulista }\end{array}$ & 10 & $\mathrm{Feb}$ \\
\hline Clavulariidae & 71.6 & Feb - May, Oct - Dec & Amphibalanus amphitrite & 57.5 & Jun - Sep \\
\hline Actiniaria & 53 & all & Amphibalanus improvisus & 82.5 & Apr - Jan \\
\hline Aiptasia pallida & 14.8 & Feb, Aug, Nov & Amphibalanus reticulatus & 75.9 & May - Jan \\
\hline Biflustra denticulata & 12.5 & Feb, Apr, May, Oct & Balanus trigonus & 13.3 & Jul - Sep \\
\hline Bugula neritina & 55.0 & May - Aug & Fistolobalanus citerosum & 74.4 & all \\
\hline Bugula stolonifera & 25.0 & Jul - Aug & Megabalanus coccopoma & 60 & May - Aug \\
\hline Electra tenella & 88.9 & all & Striatobalanus amaryllis & 20 & Feb \\
\hline Hippoporina verrili & 77.6 & Feb - Jul, Sep - Jan & $\begin{array}{l}\text { Monocorophium sp, } \\
\text { Laticorophium sp, Jassa sp }\end{array}$ & 99.1 & all \\
\hline Synoflustra annae & 21.3 & Feb - May, Nov & Diplosoma listerianum & 16.7 & Mar - Apr, Sep \\
\hline Hiatella sp. & 48.7 & all & Microcosmus exasperatus & 24.7 & $\begin{array}{l}\text { Mar - Jun, } \\
\text { Sep - Dec }\end{array}$ \\
\hline Musculus lateralis & 52.9 & Feb - Aug & Molgula phytophila & 53.2 & Jul - Nov \\
\hline Mytella charruana & 71.8 & all & Styela plicata & 31.6 & Jun - Nov \\
\hline Ostrea puelchana & 59.8 & Jan - Jul, Sep - Nov & Symplegma rubra & 30 & $\begin{array}{c}\text { Mar - May, } \\
\text { Sep - Oct }\end{array}$ \\
\hline Perna perna & 45 & May - Jul, Sep & Styelidae & 100 & Apr \\
\hline
\end{tabular}


Frequent taxa $(>70 \%$ occurrence on granite plates) were Hippoporina verrili, Electra tenella, Amphibalanus reticulatus, A. improvisus, Molgula phytophila and Styelidae (Table 2). The amphipods Monocorophium sp., Laticorophium sp. and Jassa sp., and the hydrozoans Clytia gracilis, Obelia dichotoma and Obelia bidentata were pooled because they could not be distinguished in the photographs; both groups were very common $(99 \%$ and $90 \%$ respectively). Of the introduced species, A. reticulatus was very frequent $(75.9 \%)$ on granite plates, while $G$. franciscana, $H$. sanctaecrucis, $S$. plicata and $M$. coccopoma were less frequent and $S$. amaryllis was rare (Table 2).

\section{Discussion}

Granite is usually ineffective as a natural barrier to recruitment and was colonized by most nonindigenous species. Yet, in some circumstances, granite seemed to be selective because plates were colonized by fewer species than available in Paranaguá Bay. Nonetheless, NIS colonized many plates and so we should consider colonization rate to be low, rather than accidental. Nis colonized at least one plate every month.

Studies of the fouling community in Paranaguá Bay are rather recent, with the earliest in 1987 (CORREIA and SILVA, 1990). In that study acrylic plates were suspended from buoys at three different locations, and were either replaced monthly or left for a year. One of those study sites was at the entrance to the bay which is a euhaline region having some ascidians and hydrozoans. The second was close to the yacht club and a third within the bay. In that study, 35 encrusting species were identified, of which four were native, 28 cryptogenic and three introduced (the ascidians Styela plicata and Diplosoma singulare, and the naturalized bivalve Perna perna). Diplosoma singulare has not been seen again in the bay, while $S$. plicata was found on about $30 \%$ of the granite plates from June to November (though not abundant, Table 2). It is worth noting that this NIS was found only on granite (not plastic) plates, while it was also seen on ropes and within the holes in the bricks. Styela plicata is known as a NIS in Brazil where it was first seen on Mel Island at the mouth of Paranaguá Bay in 1954 (MOURE et al., 1954). In Brazil, it is now found from Santa Catarina in the south to Pernambuco in the northeast, though less commonly north of Rio de Janeiro (FARRAPEIRA, 2007). It was not found in 2004 in samples taken from floats, concrete columns or underneath boats (NEVES et al., 2007; NEVES and ROCHA, 2008), which may be due to the timing of those collections (April, when it does not reproduce). A contemporaneous study in the bay found S. plicata only on Mel Island, growing on the shells of a small mussel culture and on an old pier (ROCHA and KREMER, 2005).

In 2004, different substrates were sampled, but only once, at the Paranaguá Yacht Club, where half the number (19) of encrusting invertebrate species was found, as compared to other studies. This included four introduced species: the hydrozoan $G$. franciscana, the polychate Polydora cornuta and the barnacles $A$. reticulatus and S. amaryllis (NEVES et al., 2007; NEVES and ROCHA, 2008). With the exception of the polychaete, all occurred on granite plates with frequencies of $25 \%, 76 \%$ and $20 \%$, respectively (Table 2). Thus, again granite is ineffective as a barrier to colonization.

It is interesting to note that the earlier study found no introduced species of barnacles (CORREIA and SILVA, 1990). Amphibalanus reticulatus was first reported in Brazil in the northeast (Pernambuco) and then in more southern states (Bahia - YOUNG, 1998; Rio de Janeiro - MAYER-PINTO and JUNQUEIRA, 2003). Similarly, S. amaryllis was first reported in Brazil in 1987 from northern (Piauí -YOUNG, 1989) and northeastern coasts (YOUNG, 1998). Thus, their occurrence in southern Brazil may be the result of continuous range extension to the south. The state of Paraná is the southern limit of the reported geographical range of $S$. amaryllis. Nonetheless, A. reticulatus has been found on polyethylene plates in a mussel farm in the more southern state of Santa Catarina (L. P. KREMER, personal communication 2008).

This study detected an additional three introduced species in Paranaguá Bay: the hydrozoan Hydractinia carnea, the serpulid Hydroides sanctaecrucis and the barnacle Megabalanus coccopoma. All occupied granite plates $(62 \%, 30 \%$ and $60 \%$ of the plates, respectively) and the least common serpulid was found only on granite. Hydractinia carnea is known from tropical waters of the western Atlantic Ocean (CAIRNS et al., 2003) and Mediterranean Sea (BOUILLON et al., 2004). Medusae were recently encountered in the state of São Paulo in the first record of the species in Brazil (MIGOTTO et al., 2002). Hydrozoans have been studied on rocky shores in the state of Paraná since 1983 by one of our team (MAH) and $H$. carnea has never been found, not even on artificial substrates in more oceanic waters.

Hydroides sanctaecrucis is a tropical sedentary fouling serpulid from the Caribbean known from the Dutch Antilles, French Guiana, Mexico, Haiti, the Gulf of Mexico and Panama, where it also occurs in the Pacific. It has also been reported from Hawaii, and recently from Singapore and Australia (LEWIS et al., 2006). The species forms large agglomerations and can become a nuisance (LEWIS et al., 2006). 
Megabalanus coccopoma is from the coasts of the tropical eastern Pacific Ocean in Central and South America and was introduced in coastal waters of southeastern and southern Brazil (JUNQUEIRA et al., 2004). Now it is apparently moving northwards and has recently been found on ship hulls in Pernambuco (FARRAPEIRA et al., 2007).

The polychate Polydora cornuta, first found in 2004, was not seen in this study, suggesting either local extinction or that competition prevented its recruitment. Alternatively, because it is cryptic and lives in bivalve shells, it may have been overlooked in this study.

Of the total of 43 cryptogenic species identified for Paranaguá Bay to date, 16 were not found in this study. Among them, O. geniculata, $R$. horsti, S. evelinae, B. nigrum, C. oblonga and $P$. constellatum do not tolerate wide variation in salinity and were mostly found on plates at the bay entrance (CORREIA and SILVA, 1990). They probably did not occur at the yacht club due to variable salinity. Corophium acherusicum is a case of taxonomic confusion, because it was found to comprise a complex of species of different genera. The remaining species either disappeared from the area, indicating that they were probably introduced, or were not found due to different sampling techniques. Finally, three of the cryptogenic species occurred only on granite plates: the bivalve $M$. lateralis and the ascidians $D$. listerianum and S. rubra, also suggesting that granite, as a substrate, does not limit settlement.

While we find that natural substrates probably do not limit introductions, additional lessons arise from this study. First, detectability of introduced species depends on the temporal scale of the study. A recent review of the methods used to survey ports and marinas around the world showed that all used short time intervals, usually days (CAMPBELL et al., 2007). Even when a study was repeated at a given location, the repeat was not seasonal, but rather was after a very long time interval, often years. Thus, two surveys per year (dry and rainy seasons) are recommended to avoid this problem (CAMPBELL et al., 2007). We would add the additional recommendation that subtropical sites should also be surveyed seasonally since the reproductive season is not as highly synchronized as in temperate regions. Moreover, the use of the "passive sampling method" (sensu CAMPBELL et al., 2007) also permits the collection of specimens on different temporal scales (days, months or years) - our study found some species only on the short term plates and others only on the long term plates (Table 3). Thus a combination of temporal scales should be used.

Table 3. Comparison of registers of encrusting species known from Paranaguá Bay.

\begin{tabular}{|c|c|c|c|c|c|}
\hline \multirow[b]{2}{*}{ Taxa } & \multirow[b]{2}{*}{ Status $^{1}$} & \multicolumn{4}{|c|}{ Substrate $^{2}$} \\
\hline & & $\begin{array}{l}\text { Acrilic }^{3} \\
1987-88\end{array}$ & $\begin{array}{l}\text { Various }^{3,4} \\
2004\end{array}$ & $\begin{array}{c}\text { Polyethylene } \\
2007-08\end{array}$ & $\begin{array}{c}\text { Granite } \\
2007-08\end{array}$ \\
\hline \multicolumn{6}{|l|}{ Hydrozoa } \\
\hline Bougainvillia muscus & $\mathrm{C}$ & $\mathrm{X}$ & & & \\
\hline $\begin{array}{l}\text { Clytia gracilis }(=\mathrm{C} . \text { sp in Correia } \\
\text { and Silva, } 1990 ;=C \text {. } \\
\text { hemisphaerica in Neves et al., } \\
\text { 2007) }\end{array}$ & $\mathrm{C}$ & $\mathrm{X}$ & $\mathrm{X}$ & $\mathrm{X}$ & $\mathrm{X}$ \\
\hline Clytia linearis & $\mathrm{C}$ & & & $\mathrm{X}$ & \\
\hline Ectopleura dumortieri & $\mathrm{C}$ & $\mathrm{X}$ & & $\mathrm{X}$ & $\mathrm{X}$ \\
\hline Eudendrium carneum & $\mathrm{C}$ & $\mathrm{X}^{*}$ & & $\mathrm{X}$ & \\
\hline Garveia franciscana & I & & $\mathrm{X}$ & $\mathrm{X}$ & $\mathrm{X}$ \\
\hline Hydractinia carnea & I & & & $\mathrm{X}$ & $\mathrm{X}$ \\
\hline $\begin{array}{l}\text { Lafoeina almirantensis Millard and } \\
\text { Bouillon, } 1973\end{array}$ & $\mathrm{C}$ & $\mathrm{X}$ & & & \\
\hline Obelia bidentata & $\mathrm{C}$ & $\mathrm{X}$ & $\mathrm{X}$ & $\mathrm{X}$ & $\mathrm{X}$ \\
\hline Obelia dichotoma & $\mathrm{C}$ & $\mathrm{X}$ & $\mathrm{X}$ & $\mathrm{X}$ & $\mathrm{X}$ \\
\hline Obelia geniculata Linnaeus, 1758 & $\mathrm{C}$ & $\mathrm{X}$ & & & \\
\hline $\begin{array}{l}\text { Pennaria disticha Goldfuss, } 1820 \\
\quad(=\text { Halocordyle disticha })\end{array}$ & $\mathrm{C}$ & $\mathrm{X}^{*}$ & & & \\
\hline $\begin{array}{l}\text { Pinauay crocea }(=\text { Ectopleura } \\
\text { warreni in Correia and Silva, } \\
\text { 1990) }\end{array}$ & $\mathrm{C}$ & $\mathrm{X}$ & & $\mathrm{X}$ & $\mathrm{X}$ \\
\hline Plumularia floridana & $\mathrm{C}$ & & & $\mathrm{X}$ & \\
\hline \multicolumn{6}{|l|}{ Anthozoa } \\
\hline Aiptasia pallida & $\mathrm{C}$ & & & $\mathrm{X}$ & $\mathrm{X}$ \\
\hline Carijoa riisei & HI & $\mathrm{X}^{*}$ & & $\mathrm{X}^{*}$ & \\
\hline Tricnidactis errans Pires, 1987 & $\mathrm{C}$ & $\mathrm{X}^{*}$ & & & \\
\hline \multicolumn{6}{|l|}{ Bryozoa } \\
\hline $\begin{array}{l}\text { Alcyonidium polyoum (Hassall, } \\
\text { 1841) }\end{array}$ & $\mathrm{C}$ & & $\mathrm{X}$ & & \\
\hline
\end{tabular}


Table 3. Continuation.

\begin{tabular}{|c|c|c|c|c|c|}
\hline \multirow[b]{2}{*}{ Taxa } & \multirow[b]{2}{*}{ Status $^{1}$} & \multicolumn{4}{|c|}{ Substrate $^{2}$} \\
\hline & & $\begin{array}{l}\text { Acrilic }^{3} \\
1987-88\end{array}$ & $\begin{array}{l}\text { Various }^{3,4} \\
2004\end{array}$ & $\begin{array}{l}\text { Polyethylene } \\
2007-08\end{array}$ & $\begin{array}{c}\text { Granite } \\
2007-08\end{array}$ \\
\hline $\begin{array}{l}\text { Bryozoa } \\
\text { Biflustra denticulata (Busk, 1856) } \\
\quad(=\text { Acanthodesia tenuis in Correia } \\
\quad \text { and Silva, 1990) }\end{array}$ & $\mathrm{C}$ & $\mathrm{X}^{*}$ & & & $\mathrm{X}$ \\
\hline $\begin{array}{l}\text { Biflustra savartii (Audouin, 1826) } \\
\text { (= Acanthodesia savartii in } \\
\text { Correia and Silva, 1990) }\end{array}$ & $\mathrm{C}$ & $\mathrm{X}$ & & & \\
\hline Bugula neritina & $\mathrm{C}$ & $\mathrm{X}$ & & $\mathrm{X}$ & $\mathrm{X}$ \\
\hline Bugula stolonifera & $\mathrm{C}$ & & & $\mathrm{X}$ & $\mathrm{X}$ \\
\hline Bugula turrita (Desor, 1848) & $\mathrm{C}$ & $\mathrm{X}$ & & & \\
\hline $\begin{array}{l}\text { Conopeum reticulum (Linnaeus, } \\
1767 \text { ) }\end{array}$ & $\mathrm{C}$ & & $\mathrm{X}$ & & \\
\hline Electra tenella & $\mathrm{C}$ & $\mathrm{X}$ & & $\mathrm{X}$ & $\mathrm{X}$ \\
\hline Hippoporina verrilli & $\mathrm{C}$ & & $\mathrm{X}$ & $\mathrm{X}$ & $\mathrm{X}$ \\
\hline $\begin{array}{l}\text { Rimulostoma horsti (Osburn, 1927) } \\
\quad(=\text { Schizoporella horsti in Correia } \\
\text { and Silva, 1990) }\end{array}$ & $\mathrm{C}$ & $\mathrm{X}$ & & & \\
\hline Sinoflustra annae & $\mathrm{C}$ & & & $\mathrm{X}$ & $\mathrm{X}$ \\
\hline $\begin{array}{l}\text { Schizoporella unicornis (Johnston, } \\
\text { 1847) }\end{array}$ & $\mathrm{C}$ & $\mathrm{X}$ & & & \\
\hline $\begin{array}{l}\text { Smittoidea evelinae (Marcus, 1937) } \\
\text { (= Smittina evelinae in Correia } \\
\text { and Silva, 1990) }\end{array}$ & $\mathrm{C}$ & $\mathrm{X}^{*}$ & & & \\
\hline \multicolumn{6}{|l|}{ Bivalvia } \\
\hline $\begin{array}{l}\text { Brachidontes cf. rodriguezi } \\
\text { (d'Orbigny, 1846) }\end{array}$ & $\mathrm{C}$ & & $\mathrm{X}$ & & \\
\hline Crassostrea rhizophorae & $\mathrm{N}$ & $\mathrm{X}$ & & & $\mathrm{X}$ \\
\hline Musculus lateralis & $\mathrm{C}$ & & & & $\mathrm{X}$ \\
\hline Musculus viator (d'Orbigny, 1846) & $\mathrm{N}$ & $\mathrm{X}$ & & & \\
\hline Mytella charruana & $\mathrm{N}$ & & $\mathrm{X}$ & & $\mathrm{X}$ \\
\hline Ostrea puelchana & $\mathrm{N}$ & & & & $\mathrm{X}$ \\
\hline Perna perna & HI & $\mathrm{X}$ & & & $\mathrm{X}$ \\
\hline $\begin{array}{l}\text { Sphenia antillensis Dall and } \\
\text { Simpson, } 1901\end{array}$ & $\mathrm{~N}$ & $\mathrm{X}$ & & & \\
\hline \multicolumn{6}{|l|}{ Polychaeta } \\
\hline Branchiomma patriota & $\mathrm{N}$ & & & & $\mathrm{X}$ \\
\hline Hydroides sanctaecrucis & I & & & & $\mathrm{X}$ \\
\hline Neanthes cf. succinea & $\mathrm{C}$ & & $\mathrm{X}$ & $\mathrm{X}^{*}$ & \\
\hline Nicolea uspiana & $\mathrm{N}$ & & & & $\mathrm{X}$ \\
\hline Polydora colonia Moore, 1907 & $\mathrm{C}$ & & $\mathrm{X}$ & & \\
\hline Polydora cf. cornuta Bosc, 1902 & I & & $\mathrm{X}$ & & \\
\hline Pseudobranchiomma paulista & $\mathrm{N}$ & & & & $\mathrm{X}$ \\
\hline \multicolumn{6}{|l|}{ Cirripedia } \\
\hline Amphibalanus amphitrite & $\mathrm{C}$ & & $\mathrm{X}$ & $\mathrm{X}^{*}$ & $\mathrm{X}$ \\
\hline Amphibalanus eburneus & $\mathrm{C}$ & $\mathrm{X}$ & & $\mathrm{X}^{*}$ & \\
\hline Amphibalanus improvisus & $\mathrm{C}$ & $\mathrm{X}$ & $\mathrm{X}$ & $\mathrm{X}^{*}$ & $\mathrm{X}$ \\
\hline Amphibalanus reticulatus & I & & $\mathrm{X}$ & $\mathrm{X}^{*}$ & $\mathrm{X}$ \\
\hline Balanus trigonus & $\mathrm{C}$ & $\mathrm{X}$ & & & $\mathrm{X}$ \\
\hline Fistulobalanus citerosum & $\mathrm{N}$ & & $\mathrm{X}$ & $\mathrm{X}^{*}$ & $\mathrm{X}$ \\
\hline Megabalanus coccopoma & I & & & $\mathrm{X}^{*}$ & $\mathrm{X}$ \\
\hline Megabalanus tintinnabulum & $\mathrm{HI}$ & & & $\mathrm{X}^{*}$ & \\
\hline Striatobalanus amaryllis & I & & $\mathrm{X}$ & & $\mathrm{X}$ \\
\hline \multicolumn{6}{|l|}{ Amphipoda } \\
\hline $\begin{array}{l}\text { Corophium acherusicum (Costa, } \\
\text { 1851) }\end{array}$ & $\mathrm{C}$ & $\mathrm{X}$ & $\mathrm{X}$ & & \\
\hline \multicolumn{6}{|l|}{ Ascidiacea } \\
\hline $\begin{array}{l}\text { Botrylloides nigrum (Herdman, } \\
\text { 1886) }\end{array}$ & $\mathrm{C}$ & $\mathrm{X}$ & & & \\
\hline Clavelina oblonga Herdman, 1880 & $\mathrm{C}$ & $\mathrm{X}$ & & & \\
\hline $\begin{array}{l}\text { Didemnum speciosum (Herdman, } \\
\text { 1886) }\end{array}$ & $\mathrm{N}$ & $\mathrm{X}$ & & & \\
\hline Diplosoma listerianum & $\mathrm{C}$ & & & & $\mathrm{X}$ \\
\hline $\begin{array}{l}\text { Diplosoma singulare Lafargue, } \\
1968\end{array}$ & I & $\mathrm{X}^{*}$ & & & \\
\hline Microcosmus exasperatus & $\mathrm{C}$ & & & & $\mathrm{X}$ \\
\hline Molgula phytophila & $\mathrm{N}$ & & $\mathrm{X}$ & $\mathrm{X}$ & $\mathrm{X}$ \\
\hline
\end{tabular}


Table 3. Continuation.

\begin{tabular}{|c|c|c|c|c|c|}
\hline \multirow[b]{2}{*}{ Taxa } & \multirow[b]{2}{*}{ Status $^{1}$} & \multicolumn{4}{|c|}{ Substrate $^{2}$} \\
\hline & & $\begin{array}{l}\text { Acrilic }^{3} \\
\text { 1987-88 }\end{array}$ & $\begin{array}{c}\text { Various } \\
2004\end{array}$ & $\begin{array}{c}\text { Polyethylene } \\
\text { 2007-08 }\end{array}$ & $\begin{array}{l}\text { Granite } \\
\text { 2007-08 }\end{array}$ \\
\hline $\begin{array}{l}\text { Ascidiacea } \\
\quad \text { Polyclinum constellatum Savigny, } \\
\quad 1816\end{array}$ & $\mathrm{C}$ & $\mathrm{X}^{*}$ & & & \\
\hline Styela plicata & I & $\mathrm{X}^{*}$ & & & $\mathrm{X}$ \\
\hline Symplegma rubra & $\mathrm{C}$ & & & & $\mathrm{X}$ \\
\hline Symplegma viride Herdman, 1886 & $\mathrm{C}$ & $\mathrm{X}$ & & & \\
\hline
\end{tabular}

${ }^{1}$ Status: $\mathrm{I}=$ introduced, $\mathrm{HI}=$ historic introduction, $\mathrm{N}=$ native, $\mathrm{C}$ = cryptogenic

${ }^{2}$ Source of the list of species: 1987-88 (Correia and Silva, 1990); 2004 (Neves et al., 2007; Neves and Rocha, 2008); polyethylene (present study); granite (present study).

${ }^{3}$ Only encrusting, tube dwellers or boring species considered; no associated fauna considered for comparison.

${ }^{4}$ Concrete columns, fiberglass floats, fiberglass or wood boat hulls.

* species observed only on succession plates

The second lesson is that when the "passive sampling method" is used to detect NIS, collections should include a variety of substrate types. Although most of the NIS detected in Paranaguá Bay colonized all available substrates, $H$. sanctaecrucis and $S$. plicata did not occupy polyethylene plates and would have remained undetected if only this type of substrate had been used. The species assembly was slightly different on each substrate analyzed and many cryptogenic species were seen on only one. The physical and chemical properties of the substrate can indeed influence recruitment (CONNELL and GLASBY, 1999; MAUGHAN, 2001; PERKOL-FINKEL and BENAYAHU, 2005) and our study suggests that the differences of species recruited on the different substrates were probably due to the substrate composition.

The baseline survey of the fouling community in Paranaguá Bay is 20 years old (CORREIA and SILVA, 1990) and we note that two of the species in that list were, in fact, introduced. In this study we re-surveyed only one of the sites of the previous study, yet we found seven new introductions in Paranaguá Bay. This rate, one new introduction every three years, seems low in comparison with those of other estuaries (COHEN and CARLTON, 1998; HEWITT et al., 2004). Still, we recognize that our study has limits to understand bioinvasion in Paranaguá Bay as it was restricted to the sessile fauna already established and reproducing. The true number of introduced species is probably greater and will be found when additional habitat types are evaluated and further taxonomic resolution is developed.

We are also concerned that natural hard substrates are uncommon in the bay, yet with the construction of piers and the port, hard substrates are rapidly becoming common. If what we know of the fouling community is very little, then we know even less of natural communities on hard substrates in the bay. We are aware of only two studies that examined natural substrates: one of intertidal hydrozoans (HADDAD, unpublished data) and the more recent study of tunicates on rocky walls (ROCHA and KREMER, 2005). The first found no species that are today considered to be introduced, and the other found one tunicate on artificial substrate. Thus we do not yet know whether the other NIS found here are already established on natural substrates.

In conclusion, Paranaguá Bay (as in other estuaries with ports) is an entrance for introduced species - the number of sessile non-native invertebrates in the area has increased in the last 20 years. Granite proved to be ineffective as a barrier to the colonization of NIS and so clearings that become available in natural communities on rocky shores are subject to their recruitment. Subsequent biological interactions are more important to determine the fate of the NIS in natural communities and more research is needed to better understand these interactions and to propose better management programs.

\section{ACKNOWLEDGEMENTS}

We would like to thank the staff of the Paranaguá Yacht Club for their kind help. We also thank the taxonomists Cinthya S. G. Santos (Polychaeta), Luiz Ricardo L. de Simone (Mollusca) and Leandro Vieira (Bryozoa) who helped with the identifications. James J. Roper reviewed the English and offered suggestions for improvement of the manuscript. LCC is grateful for the support provided by the Graduate program in Ecology and Conservation, and the fellowship from CAPES, LA thanks the Graduate program in Zoology and the fellowship from CAPES. RMR received a research grant from $\mathrm{CNPq}$.

\section{REFERENCES}

ANDERSSON, M. H.; BERGGREN, M.; WILHELMSSON, D.; ÖHMAN, M. C. Epibenthic colonization of concrete and steel pilings in a cold-temperate embayment: a field experiment. Helgol. Mar. Res., v. 63, p. 249-260, 2009. 
APOLINÁRIO, M. Cracas invasoras no litoral brasileiro. Ciênc. Hoje, v. 188, p. 44-48, 2002.

BADVE, R. M.; SONAR, M. A. Bryozoa (Cheilostomata) from Holocene, west coast of Maharashtra, India. Geobios, v. 28, p. 317-335, 1995.

BARROS, R. C.; ROCHA, R. M.; PIE, M. R. Humanmediated global dispersion of Styela plicata (Tunicata, Ascidiacea). Aquat. Invasion, v. 4, p. 45-57, 2009.

BAVESTRELLO, G.; BIANCHI, C. N.; CALCINAI, B.; CATTANEO-VIETTI, R.; CERRANO, C.; MORRI, C.; PUCE, S.; SARÀ, M. Bio-mineralogy as a structuring factor for marine epibenthic communities. Mar. Ecol. Prog. Ser., v. 193, p. 241-249, 2000.

BISBY, F. A.; RUGGIERO, M. A.; WILSON, K. L.; CACHUELA-PALACIO, M.; KIMANI, S. W.; ROSKOV, Y. R.; SOULIER-PERKINS, A.; van HERTUM, J. Species 2000 and ITIS Catalogue of Life, CDRom, 2005.

BOUILLON, J.; MEDEL, M. D.; PAGÈS, F.; GILLI, J. M.; BOERO, F.; GRAVILI, C. Fauna of the Mediterranean Hydrozoa. Sci. Mar., v. 68, p. 1-449, 2004.

BULLERI, F. Experimental evaluation of early patterns of colonization of space on rocky shores and seawalls. Mar. Environ. Res., v. 60, p. 355-374, 2005.

BULLERI, F.; CHAPMAN, M. G. Intertidal assemblages on artificial and natural habitats in marinas on the northwest coast of Italy. Mar. Biol., v. 145, p. 381-391, 2004.

CAIRNS, S. D.; CALDER, D. R.; BRINCKMANN-VOSS, A.; CASTRO, C. B.; FAUTIN, D. G.; PUGH, P. R. Common and Scientific Names of Aquatic Invertebrates from the United States and Canada: Cnidaria and Ctenophore, 2 Ed. American Fisheries Society Special Publication, n. 28, p XI+115, 2003.

CALDER, D. R. Shallow-water hydroid of Bermuda: The Athecate. R. Ontario Mus. Life Sci. Contrib., v. 148, p. $1-107,1988$

CALDER, D. R. Shallow-water hydroid of Bermuda: Superfamily Plumularioidea. R. Ontario Mus. Life Sci. Contrib., v. 161, p. 1-85, 1997.

CAMPBELL, M. L; GOULD, B.; HEWITT, C. L. Survey evaluations to assess marine bioinvasions. Mar. Poll. Bull., v. 55, p. 360-378, 2007.

CANEPARO, S. C. Análise da dinâmica espacial da ocupação antrópica em Paranaguá/Pr (1952-1996), através do uso de sistemas de informações geográficas. Rev. Ra'e Ga, v. 4, p. 111-130, 2000.

CARLTON, J. T. Biological invasions and cryptogenic species. Ecology, v. 77, p. 1653-1655, 1996.

CHAPMAN, J. W.; CARLTON, J. T. A test of criteria for introduced species: The global invasion by the isopod Synidotea laevidorsalis (Miers, 1881). J. Crust. Biol., v. 11, p. 386-400, 1991.

CHAPMAN, J. W.; CARLTON, J. T. Predicted discoveries of the introduced isopod Synidotea laevidorsalis. J. Crust. Biol., v. 14, p. 700-714, 1994.

COHEN, A. N.; CARLTON, J. T. Accelerating invasion rate in a highly invaded estuary. Science, v. 279 , p. $55-58$, 1998.

CONCEPCION, G. T.; KAHNG, S. E.; CREPEAU, M. W.; FRANKLIN, E. C.; COLES, S. L.; TOONEN, R. J. Resolving natural ranges and marine invasions in a globally distributed octocoral (genus Carijoa). Mar. Ecol. Prog. Ser., v. 401, p. 113-127, 2010.
CONNELL, S. D. Urban structures as marine habitats: an experimental comparison of the composition and abundance of subtidal epibiota among pilings, pontoons and rocky reefs. Mar. Environ. Res., v. 52, p. 115-125, 2001

CONNELL, S. D; GLASBY, T. N. Do urban structures influence local abundance and diversity of subtidal epibiota? A case study from Sydney Harbour, Australia. Mar. Environ. Res., v. 47, p. 373-387, 1999.

CORREIA, M. D.; SILVA, J. L. Caracterização das comunidades incrustantes e a fauna associada em painéis experimentais na Baía de Paranaguá, Paraná, Brasil. In: II SIMPÓSIO DE ECOSSISTEMAS DA COSTA SUL E SUDESTE BRASILEIRA, 1990, São Paulo. Anais..., São Paulo, 1990. V. 3, p. 89-110.

COUTTS, A. D. M.; MOORE, K. M.; HEWITT, C. L. Ships' sea-chests: an overlooked transfer mechanism for nonindigenous marine species? Mar. Pollut. Bull., v. 46, p. 1504-1515, 2003.

CREED, J. C.; PAULA, A. F. Substratum preference during recruitment of two invasive alien corals onto shallowsubtidal tropical rocky shores. Mar. Ecol. Prog. Ser., v. 330, p. 101-111, 2007.

FARRAPEIRA, C. M. R. Barnacles (Crustacea: Cirripedia) of the estuarine and marine areas of the port of Recife (Pernambuco, Brazil). Cah. Biol. Mar., v. 50, p. 119129, 2009.

FARRAPEIRA, C. M. R.; MELO, A.V.O.M.; BARBOSA, D.F.; SILVA, K.M.E. Ship hull fouling in the Port of Recife, Pernambuco. Brazil. J. Oceanogr., v. 55, n. 3, p. 207-221, 2007.

FAUCHALD, K. Polychaetes from intertidal areas in Panamá, with a review of previous shallow-water records. Smithson. Contrib. Zool., v. 221, p. 1-81, 1977.

FLORES, A. R.; FAULKES, Z. Texture preferences of ascidian tadpole larvae during settlement. Mar. Freshwater. Behav. Physiol., v. 41, n. 3, p. 155-159, 2008 .

GALEA, H. R.; HÄUSSERMANN, V.; FÖRSTERRA, G. Cnidaria, Hydrozoa: latitudinal distribution of hydroids along the fjords region of southern Chile, with notes on the world distribution of some species. Check List, v. 3 , n. 4, p. 308-320, 2007.

GLASBY, T. M. Surface composition and orientation interact to affect subtidal epibiota. J. Exp. Mar. Biol. Ecol., v. 248, p. 177-190, 2000.

GLASBY, T. M.; CONNELL, S. D. Orientation and position of substrata have large effects on epibiotic assemblages. Mar. Ecol. Prog. Ser., v. 214, p. 127-135, 2001.

GODOY, A. M. G. Reestruturação produtiva e polarização do mercado de trabalho em Paranaguá - PR. Rev. paran. Desenv., v. 99, p. 5-25, 2000

GOMES, P. B.; MAYAL, E. M. Histórico dos estudos das anêmonas-do-mar (Cnidaria, Actiniaria) no Brasil. Trab. Oceanogr. Univ. Fed. PE, v. 25, p. 111-119, 1997.

HAYES, K.; SLIWA, C.; MIGUS, S.; MCENNULTY, F.; DUNSTAN, P. National priority pests: Part II Ranking of Australian marine pests. Technical Report, Department of Environment and Heritage by CSIRO Marine Research, 2005. 106p. 
HASTINGS, A. B. Cheilostomatous Polyzoa from the vicinity of the Panama Canal collected by Dr. C. Crossland on the cruise of the S.Y. "St George". Proc. Zool. Soc. London, v. 47, p. 697-740, 1930.

HEWITT, C. L. Introduced and cryptogenic species in Port Phillip Bay, Victoria, Australia. Mar. Biol., v. 144, p. 183-202, 2004.

JUNQUEIRA, A. O. R.; LAVRADO, H. P.; VIANA, M. S. PINTO, M. M. Zoobentos de substrato consolidado. In: VILLAC, M. C.; FERNANDES, F. C.; JABLONSKI, S.; NETO, A. C. L; COUTINHO, B. H. (eds.), Biota da área sob influência do Porto de Sepetiba, Rio de Janeiro, Brasil: levantamento de dados pretéritos. Brasília: Ministério do Meio Ambiente, 2004, p. 47-55.

KNOTT, N. A. Epibiota on vertical and on horizontal surfaces on natural reefs and on artificial structures. J. Mar. Biol. Ass. U. K., v. 84, p. 1117-1130, 2004.

LANA, P. C.; MARONE, E.; LOPES, R. E.; MACHADO, E. C. The subtropical estuarine complex of Paranaguá Bay, Brazil. Ecol. Stud., v. 144, p. 131-145, 2001.

LEWIS, J. A.; WATSON, C.; HOVE, H. A. Establishment of the Caribbean serpulid tubeworm Hydroides sanctaecrucis Krøyer [in] Mörch, 1863, in northern Australia. Biol. Invasions, v. 8, p. 665-671, 2006.

MAUGHAN, B. C. The effects of sedimentation and light on recruitment and development of a temperate, subtidal, epifaunal community. J. Exp. Mar. Biol. Ecol. v. 256, p. 59-71, 2001

MAYER-PINTO, M.; JUNQUEIRA, A. O. R. Effects of organic pollution on the initial development of fouling communities in a tropical bay, Brazil. Mar. Poll. Bull. v. 46, p. 1495-1503, 2003.

McCANN, L. D. Non-native bryozoans in coastal embayments of the Southern United States: New records for the western Atlantic. Bull. Mar. Sci., v. 80, n. 2, p. 319-342, 2007.

MEDEL, M. D.; LÓPEZ-GONZÁLEZ, P. J. Updated catalogue of hydrozoans of the Iberian Peninsula and Balearic Islands, with remarks on zoogeography and affinities. Sci. Mar., v. 60, n. 1, p. 183-209, 1996.

MIGOTTO, A. E. Benthic shallow-water hydroids (Cnidaria, Hydrozoa) of the coast of São Sebastião, Brazil, including a checklist of Brazilian hydroids. Zoologische Verhandelingen, v. 306, p. 1-125, 1996.

MigotTO, A. E.; MARQUES, A. C.; MORANDINI, A. C.; SILVEIRA, F. L. Checklist of the Cnidaria Medusozoa of Brazil. Biota Neotrop., v. 2, p. 1-31, 2002.

MILLARD, N. A. H. Monograph on the Hydroida of southern Africa. Ann. S. Afr. Mus., v. 68, p. 1-513, 1975.

MONTOYA-CADAVID, E.; FLÓREZ-ROMERO, P ; WINSTON J. E. Checklist of the marine Bryozoa of the Colombian Caribbean. Biota Colombiana, v. 8, n. 2, p. 159-184, 2007.

MOURE, J. S.; BJORNBERG, T. K. S.; LOUREIRO, T. St. Protochordata ocorrentes na entrada da Baia de Paranaguá. Dusenia, v. 5, n. 5-6, p. 233-42, 1954

NASCIMENTO, E. F.; TORRES, M. F. A.; SOUZA, J. R. B. Registro de Nicolea uspiana (Polychaeta, Terebellidae) para o nordeste brasileiro. Bol. Téc. Cient. CEPENE, v. 15, p. 109-112, 2007.

NEVES, C. S.; ROCHA, R. M. Introduced and cryptogenic species and their management in Paranaguá Bay, Brazil.
Braz. Arch. Biol. Technol., v. 51, n. 3, p. 623-633, 2008.

NEVES, C. S.; ROCHA, R. M.; PITOMBO, F. B.; ROPER, J. J. Use of artificial substrata by introduced and cryptogenic marine species in Paranaguá Bay, southern Brazil. Biofouling, v. 23, n. 5, p. 319-330, 2007.

NOGUEIRA, J. M. M. A new species of Paraeupolymnia Young \& Kritzler, 1986 (Polychaeta, Terebellidae, Terebellinae) from Brazil. Sci. Mar., v. 67, p. 407-413, 2003.

NOGUEIRA, J. M. M.; ROSSI, M. C. S.; LOPEZ, E. Intertidal species of Branchiomma Kölliker and Pseudobranchiomma Jones (Polychaeta: Sabellidae: Sabellinae) occurring on rocky shores along the state of São Paulo, Southeastern Brazil. Zool. Stud., v. 45, n. 4, p. 586-610, 2006

ORENSANZ, J. M. L.; SCHWINDT, E.; PASTORINO, G.; BORTOLUS, A.; CASAS, G.; DARRIGRAN, G.; ELÍAS, R.; GAPPA, J. J. L.; OBENAT, S.; PASCUAL, M.; PENCHASZADEH, P.; PIRIZ, M. L.; SCARABINO, F.; SPIVAK, E. D.; VALLARINO, E. A. No longer pristine confines of the world ocean: a survey of exotic marine species in the southwestern Atlantic. Biol. Invasions, v. 4, p. 115-143, 2002.

PERKOL-FINKEL, S.; BENAYAHU, Y. Recruitment of benthic organisms onto a planned artificial reef: shifts in community structure one decade post-deployment. Mar. Environ. Res., v. 59, p. 79-99, 2005.

RAMALHO, L.V.; MURICY, G.; TAYLOR, P.D. Taxonomy and distribution of Bugula (Bryozoa: Cheilostomata: Anasca) in Rio de Janeiro State, Brazil. In: MOYANO, H.G.; CANCINO, J. M.; WISE JACKSON, P. N. (Eds), Bryozoan Studies 2005: Proceedings of the Thirteenth Conference, International Bryozoology Association - Concepción, 12-16 January 2004. A.A. Balkema Publishers, Leiden, p. 231-243, 2005 .

RIOS, E. C. Seashells of Brazil. Rio Grande do Sul: Fundação Universidade de Rio Grande, Museu Oceanográfico. 1994

ROCHA, C. E. F. Maxillopoda. In: MIGOTTO, A.E. and TIAGO, C.G. (eds.), Biodiversidade do Estado de São Paulo, Brasil: síntese do conhecimento ao final do século XX, 3: Invertebrados Marinhos. São Paulo: FAPESP, 1999. p. 207-216.

ROCHA, R. M.; KREMER, L. P. Introduced ascidians in Paranaguá Bay, Paraná, southern Brazil. Rev. bras. Zool., v. 22, n. 4, p. 1170-1184, 2005.

ROCHA, R. M.; MORENO, T. R. Ascidians associated with Eudistoma carolinense Van Name, 1945 with description of a new species of Polycarpa. Ophelia, v. 52, p. 9-16, 2000.

RUIZ, G.; CARLTON, M. J. T.; GROSHOLZ, E. D.; HINES, A. H. Global invasions of marine and estuarine habitats by non-indigenous species: mechanisms, extent, and consequences. Amer. Zool., v. 37, p. 621-632, 1997.

SCHLENZ, E.; BELÉM, M. J. C.; ZAMPONI M. O.; ACUÑA, F. Distribution and some ecological aspects of Corallimorpharia and Actiniaria from shallow waters of the South American Atlantic coasts. Physis, v. 55, n. 128 , p. $31-45,1998$. 
SKINNER, L. F.; COUTINHO, R. Effect of microhabitat distribution and substrate roughness on barnacle Tetraclita stalactifera (Lamarck, 1818) settlement. Braz. Arch. Biol. Technol., v. 48, p. 109-113, 2005.

STACHOWICZ, J. J.; BRUNO, J. F.; DUFFY, J. E. Understanding the effects of marine biodiversity on communities and ecosystems. Annu. Rev. Ecol. Evol. Syst., v. 38, p. 739-766, 2007.

STREFTARIS, N.; ZENETOS, A.; PAPATHANASSIOU, E. Globalization in marine ecosystems: the story of nonindigenous marine species across European seas. Ocean. Mar. Biol., v. 43, p. 419-453, 2005.

VIEIRA, L. M.; MIGOTTO, A. E.; WINSTON, J. E Synopsis and annotated checklist of recent marine Bryozoa from Brazil. Zootaxa, v. 1810, p. 1-39, 2008.

WINSTON, J. E. Marine Bryozoans (Ectoprocta) of the Indian River area (Florida). Bull. Amer. Mus. Nat. Hist., v. 173, p. 99-176, 1982.

WINSTON, J. E. Re-description and revision of Smitt's "Floridan Bryozoa" in the collection of the Museum of Comparative Zoology, Harvard University. Virginia Mus. Nat. Hist. Mem., v. 7, p. 1-147, 2005.
WYATT, A. S. J. Marine introduction in the Shark Bay World Heritage Property, Western Australia: a preliminary assessment. Diversity Distrib., v. 11, p. 3344, 2005.

ZULLO, V. A. Balanus trigonus Darwin (Cirripedia, Balaninae) in the Atlantic Basin: an introduced species? Bull. Mar. Sci., v. 50, p. 66-74, 1992.

YOUNG, P. S. Establishment of an Indo-Pacific barnacle in Brazil. Crustaceana, v. 56, p. 12-214, 1989.

YOUNG, P. S. Maxillopoda. Thecostraca. In: YOUNG, P. S (Ed.) Catalogue of Crustacea from Brazil, Série Livros 7, Rio de Janeiro, p. 263-285, 1998.

(Manuscript received 05 November 2009; revised 14 April 2010; accepted 06 May 2010) 